\title{
Efficiency of natural adaptogens for organic products
}

\author{
$N$ Yarovan $^{1}, E$ Bondarenko $^{2}, O$ Boytsova $^{3}, A$ Sergachev $^{1}, N$ Komissarova $^{1}$ \\ ${ }^{1}$ Orel State Agrarian University, 69, General Rodina str., Orel, 302019, Russia \\ ${ }^{2}$ Oryol branch of "Central Scientific and Methodological Veterinary Laboratory", 18, Novosilskoe sh., Orel, 302031, \\ Russia \\ ${ }^{3}$ LLC "MedLine", 96, Dubrovinsky Emb, Orel, 302030, Russia.
}

\begin{abstract}
In the conditions of modern anthropogenic pollution of the environment, the creation of organic agricultural products becomes ever more relevant. The production of organic products requires special technologies, namely, production without the use of agrochemicals, antibiotics, hormones, preparations that stimulate the animal growth and fattening, as well as pesticides. Pesticide use causes both acute and chronic poisoning of humans and animals. The paper presents the study of feed, meat and dairy products for the presence of pesticides. Our studies on pesticide content in food products from Oryol Oblast showed a small number of pesticides: hexachloride, dichlordiphenyl trichlormethyl methane and glyphosate. However, according to the Federal Law No. 280 of 03.08.2018 "On Organic Products and on Amending Certain Legislative Acts of the Russian Federation", even such an amount of pesticides does not allow attributing products to organic. The purpose of the study was to normalize the biochemical status of highproducing cows in the conditions of the industrial complex, which would allow obtaining organic products. As such, we proposed and tested the action of nettle, lecithin, sprout wheat grain, common thyme, Khotynets natural zeolites and marsh cinquefoil. Their positive effect is confirmed by the improvement of the studied biochemical blood values.
\end{abstract}

\section{Introduction}

In recent years, new groups of chemical crop protection products have been increasingly introduced in agricultural production, while it is noted that the high economic potential of chemical agents unreasonably increases the risk of negative effects of their metabolites on the human and animal body $[17,18,19]$.

Toxic effects of pesticides may be considered as a component of technological stress, which requires adaptive agents rich in bioactive compounds, in particular vitamins and mineral elements, to the basic diet $[9,13]$. As such, we used compositions of nettle, lecithin, sprout wheat grains, common thyme, Khotynets natural zeolites and marsh cinquefoil.

Stinging nettle is a perennial herbaceous plant. Its leaves, roots and seeds have long been used as medicines. Biologically active substances of nettle are represented by: gilicoside, urticin, tannins, organic acids (citric formic, fumaric, quinic, oxalic, amber), protoporphyrin, quercetin, phytosterol, distamine, wax, vitamins :B2, B3, K, E (25 mg/100g), C (2.5 times more than in lemons), a significant amount of carotenoids: beta-karatin, xanthophyll, xanthophylepoxide, chlorophyll (2-5\%) [2].

Nettle leaves contain $14.4 \%$ of macronutrients in ash $(\mathrm{mg} / \mathrm{g})$ : potassium - 34.2; calcium - 37.4; magnesium-
6.0 ; iron -0.3 ; trace elements $(\mathrm{mg} / \mathrm{g})$ : manganese -0.32 , copper -0.8 , zinc -0.5 , cobalt -0.13 , chromium -0.06 , aluminum -0.11 , barium 16.64 , selenium -10.5 , nickel -0.12 , and also contains a large amount of molybdenum, which stimulates the formation of hemoglobin, it affects purine metabolism, and prevents the deposition of salts in the body [1].

It has been established that lecithin is able to perform various functions in the body. On its basis, pharmacological agents of various actions are produced. The source of phospholipids in Russia is secondary products formed during the production of sunflower oil.

Lecithin is represented by a complex of essential phospholipids:

phosphatidylethanolamine and which perform various functions: it is part of cell membranes (phosphatidylcholine); participates in the emulsification and regulation of cholesterol crystallization; it is the main component of acetylcholine and a supplier of methyl groups.

With the participation of lecithin and other phospholipids, the structure and permeability of cell membranes are maintained, without which the vital activity of cells, the assimilation of nutrients, and the transfer of intercellular information is impossible. With the help of phospholipids, the work of proteins entering the membranes and neurotransmitters is regulated.

An important role of lecithin is in the formation of the body's immunity. Lecithin promotes resistance to 
diseases, while antibodies are more actively produced, phagocyte activity is stimulated, foreign and pathological tissues are destroyed [10].

Studies by A. F. Ponomarev and other authors have shown that sprouted grain becomes a dietary feed containing carotene and a number of other vitamins (A, C, E) $[11,12]$, and is also a source of calcium, phosphorus, potassium, sulfur, magnesium, iron, copper, zinc, manganese, cobalt and iodine. When using it, the feed palatability and the digestibility of macro and microelements improves.

Thyme is included in the State Pharmacopoeia of the Russian Federation as a medicinal plant raw material having the following properties: antibacterial, astringent, anti-inflammatory, soothing, anticonvulsant, expectorant, antispasmodic, choleretic, analgesic, diuretic, wound healing [3, 6, 7]. Its decoctions and infusions are used.

Modern studies have established that thyme contains not only essential oil, but also flavonoids, rosemary acid, tannins and other biologically active compounds, such as thymol, carvacrol and apigenin, which have antiseptic, antibacterial and antioxidant properties.

In our research, natural zeolites were used, which were mined in the Khotynetsky district of the Orel region. The biological effect of Khotynets natural zeolites is based on their adsorption, catalytic and ion exchange properties. They contain more than 40 macroand microelements that are in a biologically digestible form [21, 22].

Marsh sabelnik is a perennial herbaceous plant that grows in damp swampy places. Having a pronounced anti-inflammatory activity and the absence of side effects, sabelnik is a more preferable, effective and safe remedy for the prevention and treatment of a number of inflammatory diseases in comparison with synthetic drugs [4]. Sabelnik leaves contain tannins (up to 12.5\%), ascorbic acid (431 $\mathrm{mg} \%)$, beta-carotene (19 $\mathrm{mg} \%$ ), phenol-carboxylic acids (en-fumaric, synpic, serulic, ellagic) (6author), as well as flavonoids; the herb contains ascorbic acid (185 mg\%), beta-carotene (17.5 $\mathrm{mg} \%)$, tannins and flavonoids. The aboveground part of the sabelnik contains macronutrients in $\mathrm{mg} / \mathrm{g}$ of potassium-10.8, calcium-11.9, magnesium-5.2, iron-0.7; as well as trace elements $(\mathrm{mcg} / \mathrm{g})$ of manganese -128.0 , copper -8.16 .

The composition and biological effect of the products offered by us when they are used in agricultural production allows us to obtain organic products.According to EU Regulation No. 834/2007 of 28.062007 , organic animal husbandry provides for breeding animals only in organic enterprises and the use of more small local breeds. It is acceptable to ensure exclusively humane management of animals in compliance with the requirements to premises, and only their yard housing. The animals are fed with the feed of its own production, the use of feed of animal origin is prohibited for ruminants, synthetic feed additives, amino acids, growth stimulants are also not allowed. The use of chemical agents is prohibited (in addition to the necessary veterinary treatment 2 times a year). The time to use the animal product after treatment is doubled [9].

According to GOST R 56508-2015, many positions coincide with the EU regulations, but are even more humane (for example, all animals should have access to pastures, grazing and walking areas, at least $50 \%$ should be fed with products of their own production, any suffering is minimized) [5].

The Federal Law No. 280 of 03.08.2018 "On organic products and on amendments to certain legislative acts of the Russian Federation" describes the concept of organic products as environmentally friendly agricultural products, raw materials and food, which production meets the requirements specified in this legislation $[8$, 15].

The production of organic products requires special technologies, namely, without the use of agrochemicals, antibiotics, hormones, preparations that stimulate growth and fattening of animals, as well as pesticides $[5,9,15]$.

The use of pesticides entails some local and shortterm benefits; however, in general, their use leads to a number of problems, including economic ones. The sustainable and significant benefits of pesticides come from the companies that produce them.

The use of pesticides causes both acute and chronic poisoning of people. In some cases, the number of pesticides increases along food chains.

\section{Research results}

The pesticide content in food products (meat products, sausages, patties, as well as milk and dairy products) is determined at the analytical complex based on a liquid mass-spectrometer. Our studies on pesticide content in food products from Oryol Region showed a small number of pesticides: hexachloride, dichlordiphenyl trichlormethyl methane and glyphosate. Thus, Table 1 shows the pesticide content in the products of ORLOVSKAYA NIVA AGRO-INDUSTRIAL COMPLEX JSC and MASLOVO LLC.

The presence of such amount of pesticides in the studied products meets the requirements of TR CU 021/2011 "On Food Safety", however, according to EU Regulation No. 834/2007 and the Federal Law No. 280 of 03.08.2018 "On Organic Products and on Amendments to Certain Legislative Acts of the Russian Federation", such products cannot be classified as organic $[15,16]$. The main sources of meat and milk pollution are feed for farm animals and water. The accumulation of pesticides in the animal body is determined by the dose, source and duration of entry into the body. Pesticides are likely to enter food in different ways $[17,18,19,20]$. The results of our studies also showed the presence of pesticides in feed, which explains their appearance in meat and dairy products (Table 2). 
Table 1. Pesticide content in food products

\begin{tabular}{|c|c|c|c|c|c|c|}
\hline \multirow[t]{4}{*}{ Name } & \multicolumn{6}{|c|}{ Pesticide content, $\mathrm{mg} / \mathrm{kg}$} \\
\hline & \multirow{2}{*}{$\begin{array}{l}\text { ORLOVSKAYA } \\
\text { NIVA AGRO- } \\
\text { INDUSTRIAL } \\
\text { COMPLEX JSC }\end{array}$} & \multirow{2}{*}{$\begin{array}{l}\text { MASLOVO } \\
\text { LLC }\end{array}$} & ORLOVSKAYA & \multirow{2}{*}{$\begin{array}{l}\text { MASLOVO } \\
\text { LLC }\end{array}$} & ORLOVSKAYA & \multirow{2}{*}{$\begin{array}{l}\text { MASLOVO } \\
\text { LLC }\end{array}$} \\
\hline & & & $\begin{array}{l}\text { NIVA AGRO- } \\
\text { INDUSTRIAL } \\
\text { COMPLEX JSC }\end{array}$ & & $\begin{array}{l}\text { NIVA AGRO- } \\
\text { INDUSTRIAL } \\
\text { COMPLEX JSC }\end{array}$ & \\
\hline & \multicolumn{2}{|c|}{ Hexachloride (sum of isomers) } & \multicolumn{2}{|c|}{$\begin{array}{l}\text { Dichlordiphenyl trichlormethyl } \\
\text { methane (sum of metabolites) }\end{array}$} & \multicolumn{2}{|l|}{ Glyphosate } \\
\hline $\begin{array}{l}\text { Meat } \\
\text { products } \\
\text { (beef) }\end{array}$ & $0.0001-0.0013$ & $\begin{array}{l}0.0002- \\
0.0014\end{array}$ & $0.0001-0.0037$ & $\begin{array}{l}0.0002- \\
0.0038\end{array}$ & $0.0002-0.0013$ & $\begin{array}{l}0.0001- \\
0.0013\end{array}$ \\
\hline $\begin{array}{l}\text { Dairy } \\
\text { products } \\
(\text { milk) }\end{array}$ & $0.0001-0.0014$ & $\begin{array}{l}0.0003- \\
0.0016\end{array}$ & $0.00009-0.0041$ & $\begin{array}{l}0.00010- \\
0.0042\end{array}$ & $0.0003-0.0011$ & $\begin{array}{l}0.0001- \\
0.0011\end{array}$ \\
\hline
\end{tabular}

Table 2. Pesticide content in feed

\begin{tabular}{|l|l|l|l|l|l|l|}
\hline \multirow{2}{*}{ Name } & \multicolumn{3}{|c|}{ Pesticide content, mg/kg } \\
\cline { 2 - 7 } & $\begin{array}{l}\text { ORLOVSKAYA } \\
\text { NIVA AGRO- }\end{array}$ & $\begin{array}{l}\text { MASLOVO } \\
\text { INDUSTRIAL } \\
\text { COMPLEX JSC }\end{array}$ & $\begin{array}{l}\text { ORLOVSKAYA } \\
\text { NIVA AGRO- } \\
\text { INDUSTRIAL } \\
\text { COMPLEX JSC }\end{array}$ & $\begin{array}{l}\text { MASLOVO } \\
\text { LLC }\end{array}$ & $\begin{array}{l}\text { ORLOVSKAYA } \\
\text { NIVA AGRO- } \\
\text { INDUSTRIAL } \\
\text { COMPLEX JSC }\end{array}$ & $\begin{array}{l}\text { MASLO } \\
\text { LLO }\end{array}$ \\
\cline { 2 - 7 } & Hexachloride (sum of isomers) & $\begin{array}{l}\text { Dichlordiphenyl trichlormethyl } \\
\text { methane (sum of metabolites) }\end{array}$ & Glyphosate \\
\hline $\begin{array}{l}\text { wheat } \\
\text { for } \\
\text { feed }\end{array}$ & $0.3-0.35$ & $0.35-0.38$ & $0.11-0.16$ & $0.10-0.15$ & $0.10-0.17$ & $0.12-0.15$ \\
\hline $\begin{array}{l}\text { barley } \\
\text { for } \\
\text { feed }\end{array}$ & $0.02-0.06$ & $0.01-0.05$ & $0.02-0.06$ & $0.01-0.05$ & $0.01-0.06$ & $0.02-0.07$ \\
\end{tabular}

The toxic effects of pesticides included in the feed undoubtedly lead to violations of the biochemical status of animals, and therefore to poor health, productivity and quality of products. Moreover, in industrial complexes, pesticides are not the only factor causing a stressproducing effect and disruption of metabolic processes. The purpose of the study was to find means to normalize the biochemical status of high-producing cows in the conditions of industrial complex. As such, we proposed and tested the effect of nettle, lecithin, sprout wheat grains, common thyme, Khotynets natural zeolites and marsh cinquefoil. The data in Tables 3, 4 confirm the positive effect of these plants on a number of biochemical parameters.

Table 3. Effect of additional introduction of nettle, lecithin and sprout wheat grain composition into cow feeding on biochemical status in ORLOVSKAYA NIVA AGRO-INDUSTRIAL COMPLEX JSC

\begin{tabular}{|c|c|c|c|c|}
\hline Group & Indicator & $\begin{array}{l}\text { Physiological } \\
\text { standard }\end{array}$ & $\begin{array}{l}1^{\text {st }} \text { day of the } \\
\text { experiment }\end{array}$ & $\begin{array}{l}29^{\text {th }} \text { day of the } \\
\text { experiment }\end{array}$ \\
\hline 1 & 2 & 3 & 4 & 6 \\
\hline \multirow[t]{4}{*}{$\begin{array}{l}\text { Control ( } 2 \text { weeks after calving: } \\
\text { basic diet) }\end{array}$} & $\begin{array}{l}\text { Total lipids, } \\
\text { g/l }\end{array}$ & $3.5-5.0$ & $4.23 \pm 0.06$ & $4.24 \pm 0.06$ \\
\hline & $\begin{array}{l}\text { Cholesterol, } \\
\mathrm{mmol} / \mathrm{L}\end{array}$ & $1.3-4.42$ & $5.05 \pm 0.04$ & $5.11 \pm 0.04$ \\
\hline & $\begin{array}{l}\text { Total protein, } \\
\mathrm{g} / \mathrm{l}\end{array}$ & $72-86$ & $76.26 \pm 0.24$ & $76.04 \pm 0.20$ \\
\hline & $\begin{array}{l}\text { Glucose, } \\
\mathrm{mmol} / \mathrm{L}\end{array}$ & $2.22-3.33$ & $1.93 \pm 0.01$ & $1.91 \pm 0.03$ \\
\hline \multirow[t]{4}{*}{$\begin{array}{l}\text { Experimental ( } 2 \text { weeks after calving: basic } \\
\text { diet }+ \text { nettle }+ \text { lecithin }+ \text { sprout wheat grains) }\end{array}$} & $\begin{array}{l}\text { Total lipids, } \\
\text { g/l }\end{array}$ & $3.5-5.0$ & $4.24 \pm 0.05$ & $3.88 \pm 0.04^{* * *}$ \\
\hline & $\begin{array}{l}\text { Cholesterol, } \\
\mathrm{mmol} / \mathrm{L}\end{array}$ & $1.3-4.42$ & $5.15 \pm 0.04$ & $4.47 \pm 0.05^{* * *}$ \\
\hline & $\begin{array}{l}\text { Total protein, } \\
\mathrm{g} / \mathrm{l}\end{array}$ & $72-86$ & $76.50 \pm 0.54$ & $78.60 \pm 0.48^{* *}$ \\
\hline & $\begin{array}{l}\text { Glucose, } \\
\mathrm{mmol} / \mathrm{L}\end{array}$ & $2.22-3.33$ & $1.86 \pm 0.03$ & $2.23 \pm 0.02^{*}$ \\
\hline
\end{tabular}

Note: $*-\mathrm{P}<0.05 ; * *-\mathrm{P}<0.01 ; * * *-\mathrm{P}<0.001$ in relation to the animal of the control group 
Table 4. Efficiency of common thyme, Khotynets natural zeolites and marsh cinquefoil in feeding cows in MASLOVO LLC

\begin{tabular}{|c|c|c|c|c|}
\hline Group & Indicator & $\begin{array}{l}\text { Physiological } \\
\text { standard }\end{array}$ & $\begin{array}{l}1^{\text {st day of the }} \\
\text { experiment }\end{array}$ & $\begin{array}{l}29^{\text {th }} \text { day of the } \\
\text { experiment }\end{array}$ \\
\hline 1 & 2 & 3 & 4 & 6 \\
\hline \multirow{5}{*}{$\begin{array}{l}\text { Control } \\
\text { ( } 2 \text { weeks after calving: } \\
\text { basic diet) }\end{array}$} & $\begin{array}{l}\text { Cholesterol, } \\
\mathrm{mmol} / \mathrm{L}\end{array}$ & $1.3-4.42$ & $4.85 \pm 0.104$ & $4.322 \pm 0.233$ \\
\hline & $\mathrm{TG}, \mathrm{mmol} / \mathrm{L}$ & $0.22-0.60$ & $0.894 \pm 0.02$ & $0.832 \pm 0.02$ \\
\hline & HDL, unit & $0.8-1.7$ & $0.73 \pm 0.009$ & $0.684 \pm 0.017$ \\
\hline & LDL, unit & $2.0-4.1$ & $4.37 \pm 0.078$ & $4.448 \pm 0.113$ \\
\hline & VLDL, unit & $0.3-0.9$ & $0.95 \pm 0.017$ & $0.919 \pm 0.023$ \\
\hline \multirow{5}{*}{$\begin{array}{l}\text { Experimental } \\
\text { ( } 2 \text { weeks after calving: basic } \\
\text { diet } \\
+ \text { common thyme } \\
+ \text { Khotynets natural zeolites) }\end{array}$} & $\begin{array}{l}\text { Cholesterol, } \\
\mathrm{mmol} / \mathrm{L}\end{array}$ & $1.3-4.42$ & $4.70 \pm 0.19$ & $3.788 \pm 0.237$ \\
\hline & $\mathrm{TG}, \mathrm{mmol} / \mathrm{L}$ & $0.22-0.60$ & $0.93 \pm 0.012$ & $0.538 \pm 0.014$ \\
\hline & HDL, unit & $0.8-1.7$ & $0.68 \pm 0.012$ & $1.368 \pm 0.035$ \\
\hline & LDL, unit & $2.0-4.1$ & $4.55 \pm 0.081$ & $2.932 \pm 0.075$ \\
\hline & VLDL, unit & $0.3-0.9$ & $0.96 \pm 0.017$ & $0.606 \pm 0.015$ \\
\hline \multirow{5}{*}{$\begin{array}{l}\text { Experimental } \\
\text { ( } 2 \text { weeks after calving: basic } \\
\text { diet } \\
+\quad \text { fresh extract of marsh } \\
\text { cinquefoil) }\end{array}$} & $\begin{array}{l}\text { Cholesterol, } \\
\mathrm{mmol} / \mathrm{L}\end{array}$ & $1.3-4.42$ & $4.68 \pm 0.18$ & $3.612 \pm 0.231$ \\
\hline & $\mathrm{TG}, \mathrm{mmol} / \mathrm{L}$ & $0.22-0.60$ & $0.91 \pm 0.010$ & $0.536 \pm 0.013$ \\
\hline & HDL, unit & $0.8-1.7$ & $0.70 \pm 0.011$ & $1.265 \pm 0.033$ \\
\hline & LDL, unit & $2.0-4.1$ & $4.45 \pm 0.071$ & $2.941 \pm 0.069$ \\
\hline & VLDL, unit & $0.3-0.9$ & $0.95 \pm 0.016$ & $0.513 \pm 0.013$ \\
\hline
\end{tabular}

Note: $*-\mathrm{P}<0.05 ; * *-\mathrm{P}<0.01 ; * * *-\mathrm{P}<0.001$ in relation to the animal of the control group.

\section{Conclusion}

Currently, agricultural production uses technologies with relatively extensive pesticide use, which prevents ecological crop production and ecological (organic) animal husbandry. In this regard, it is promising to use natural adaptogens in order to normalize metabolic processes and minimize the toxic effects of pesticides, as one of the factors of technological stress in the conditions of industrialization of agricultural production.

\section{References}

1. A.V. Abramchuk, G. G. Kartasheva. Medicinal plants of the Urals (Yekaterinburg, 2010)

2. A.V. Abramchuk, S. K. Mingalev Cultivated medicinal plants. Assortment, properties, cultivation technology (Yekaterinburg, 2004).

3. A.M. Akhmetalimova, S. B. Akhmetova, KoronaGlowniak, I. V. Loseva, S. A. Ivasenko Medicine and ecology, 4 (85), 74-77, (2017)

4. S. V. Golubev, A. A. Efremov Chemistry of plant raw materials, 1, 105-109, (2012)

5. GOST R 56508-2015 Organic products. Rules of production, storage, transportation.
6. State Pharmacopoeia of the USSR, XI, 2, (Moscow, 1990)

7. State Pharmacopoeia of the Republic of Kazakhstan, 2 (Astana, 2009)

8. Decree of the President of the Russian Federation 2018 National and strategic tasks of the development of the Russian Federation for the period until 2024

9. EU Regulation No. 834/2007: Rules for the Production of Organic Products.

10. M. A. Ogai, E. F. Stepanova, V. V. Malyavina Scientific Vedomosti BelGAU. Medicine series. Pharmacy, 22 (117), 16/2, 159-163 (2011).

11. A.F. Ponomarev, G.S. Pokhodnya, G.V. Eskin Pig production and pork production technology. (Belgorod: Peasant business, 2001).

12. G.S. Pokhodnya Pig production and pork production technology. (Belgorod, 2009).

13. V.E. Torikov, N.A. Sokolov Theoretical foundations of organic production Bulletin of Bryansk State Agricultural Academy, 4 (74), 2833 (2019)

14. Technical Regulations of the Customs Union TR CU 015/2011 “On Grain Safety”

15. Technical Regulations of the Customs Union TR CU 021/2011 “On Food Safety” 
16. Federal Law No. 280-FZ On Organic Products and on Amending Certain Legislative Acts of the Russian Federation

17. V.P. Yaremchuk, D.I. Udavliev, E.V. Pavlova, I.V. Glazkova, I.M. Nityaga, I.Kh. Alieva Problems of veterinary sanitation, hygiene and ecology 3(19) 20-24 (2016)

18. K. I. Privalo, E.E. Sivak, N.A. Kostenko Regional Bulletin. 3 (8), 48, (2017)

19. E.V. Veklenko, E.N. Nozdracheva, Yu.N. Vorobiev Bulletin of Kursk State Agricultural Academy, 8, 75-78, (2015)

20. V.I. Veklenko, I. Ya. Pigorev, N.D. Zhmakina Bulletin of Kursk State Agricultural Academy, 8, 73-75 (2015).

21. N.I. Yarovan, D. S. Achasov, Vestnik OrelGAU. 3(66), 89-93, (2017)

22. N. I. Yarovan Bulletin of the OrelGAU, 79-83, (2007) 